\title{
Religiosity as a moderating variable on the effect of love of money, Machiavellian and equity sensitivity on the perception of tax evasion
}

\author{
Pande Putu Ditha Purnamasari ${ }^{a^{*}}$, Maria M. Ratna Saria ${ }^{a}$ I Made Sukartha ${ }^{a}$ and Gayatria
}

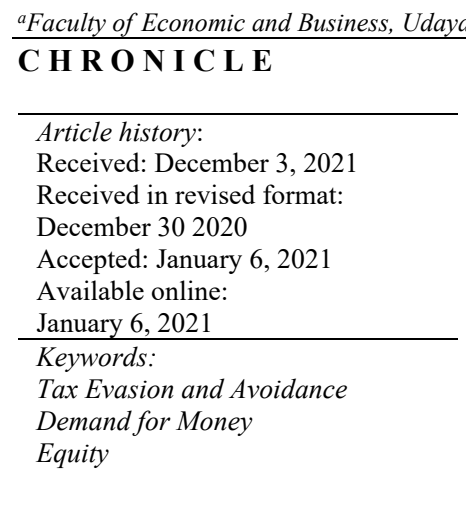

\begin{abstract}
This study aims to obtain an empirical evidence on how religiosity is moderating the effect of love of money, Machiavellian, and equity sensitivity on the perception of tax evasion. The populations in this study are individual taxpayers registered in all Pratama tax offices in Bali. Sampling was determined using the probability sampling method with proportional stratified random sampling technique. This study uses 400 research samples. The data analysis technique used is multiple linear regression analysis and moderated regression analysis. The test results provide empirical evidence that love of money and Machiavellian have a positive effect on the perception of tax evasion, however, equity sensitivity has no effect on the perception of tax evasion. The results of subsequent tests provide empirical evidence that intrinsic religiosity and extrinsic religiosity can moderate the effects of love of money, Machiavellian, and equity sensitivity on perceptions of tax evasion.
\end{abstract}

C 2021 by the authors; licensee Growing Science, Canada

\section{Introduction}

This research was conducted based on the phenomenon of how taxpayer compliance is related to tax reporting. Taxes provide a large enough contribution to the state because by taxes received by the state could help in achieving public welfare. According to Law Number 28 of 2007 concerning General Provisions and Procedures for Taxation Article 1 paragraph 1, taxes are mandatory contributions to the state that are owed by an individual or entity that is compelling under the Law, without receiving direct compensation and used for purposes the state for the greatest prosperity of the people. According to McGee and Shopovski (2018) taxes are the main instrument to finance State activities in providing public goods and services. From this definition, it shows that there is one party that is obliged to pay taxes (the people) but the other party (the government) is not obliged to provide direct fees to the taxpayers (the people). This difference in interests causes taxpayers to tend to reduce the amount of tax payments, both legally and illegally (Budiarto et al., 2018). The taxpayer's efforts to achieve his wish are prone to fraud which is a form of noncompliant taxpayers. The level of compliance of individual taxpayers in Bali Province in 2015-2018 can be seen in Table 1. Table 1 shows that the taxpayer (WPOP) compliance in submitting the annual tax return (SPT) from 2016 to 2019 continues to increase every year. Bali Province has seven Primary Tax Service Offices (KPP), which are the locations of this research. We are choosing the location of this study because the perceptions of tax evasion of each individual are different and compliance in paying taxes. Researchers use the increase in the percentage of taxpayer compliance to make it easier to get respondents because many taxpayers report their taxes. However, the percentage of compliance has not reached $100 \%$, which means there are still WPOPs who are not yet compliant to pay taxes, so that the tax revenue obtained is not optimal. This indicates that the practice of tax evasion has occurred in Indonesia. Many factors cause WPOP to be disobedient in carrying out their obligations to pay taxes, one of which is when there are many cases of tax evasion that occur. If taxpayers and tax officers commit tax evasion, it will damage individual

\footnotetext{
* Corresponding author

E-mail address: dithapurnamapande@gmail.com (P. P. D. Purnamasari)
} 
morale where taxpayers who were previously tax-compliant will have the thought of committing tax evasion due to the possibility of tax evasion being not detected by the tax authorities, and other taxpayers also do the same.

Table 1

Individual Taxpayer Compliance Levels at KPP Pratama All Bali, 2015-2019

\begin{tabular}{cccc}
\hline No & Years & Taxpayer Who Submitted The Annual Tax Return (SPT) & Obedience \\
\hline 1 & 2016 & 268.570 & $70.11 \%$ \\
2 & 2017 & 265.618 & $70.56 \%$ \\
3 & 2018 & 263.614 & $86.61 \%$ \\
4 & 2019 & 284.878 & $94.95 \%$ \\
\hline Source
\end{tabular}

Source : Kantor Wilayah DJP Bali, 2020

If taxpayers and tax officers commit tax evasion, it will damage individual morale where taxpayers who were previously taxcompliant will have the thought of committing tax evasion due to the possibility of tax evasion being not detected by the tax authorities, and other taxpayers also do the same (Dhanayanti, \& Suardana, 2017). The cases of tax evasion that occurred in Indonesia can be seen in Table 2 .

Table 2

Tax evasion case

\begin{tabular}{lll}
\hline No & Years & Tax evasion case \\
\hline 1 & 2015 & Case "DS" Director CV. TC in Bandung which is not deposit the collected VAT \\
2 & 2015 & DP (alias: AK) the commissioner of PT SEP, having his address in Tangerang Regency, reduces the amount of tax with a fictitious invoice \\
3 & 2018 & Albon S is a suspect in billboard tax corruption \\
4 & 2018 & The head and staff of Ambon KPP Pratama were arrested by the KPK for a bribery case \\
5 & 2019 & Taxpayers are in arrears for two years with a value of Rp. 4.4 billion \\
6 & 2019 & Darwin Maspolim with the alleged bribery case \\
\hline & 2020 & Hanging Garden Bali Hotel Tax evasion \\
\hline
\end{tabular}

Sources: www.pajak.go.id, www.ortax.org and www.tribunnews.com

From these cases of tax evasion, this indirectly forms the perception of the taxpayer regarding the behavior of tax evasion. According to Nugraheni and Purwanto (2015), a higher number of cases of tax evasion leads a decrease the taxpayer compliance. The existence of cases of tax evasion causes people to lose their sense of trust in tax persons and in the state because they are worried that the taxes they deposit will be misused by irresponsible parties and in the end a perception arises in the minds of taxpayers regarding tax evasion (Dhanayanti, KM \& Suardana, 2017). According to Mardiasmo (2016: 11) tax evasion is an effort made by taxpayers to ease the tax burden in a way that is not legal or violates the law. In practice, the ethics of tax evasion is seen from more than one side so that it can be classified as prohibited or even permissible (Sofha \& Machmuddah, 2019). According to Mujiyati et al. (2018), tax evasion behavior is illegal behavior because it violates applicable laws or regulations. However, in practice the behavior would be ethical or reasonable to do. In addition to cases of tax evasion that make people reluctant to pay taxes, there are factors within the taxpayers themselves that cause taxpayers to obey. This intrinsic factor for paying taxes is then known as the tax morale. These factors made the researcher choose the variables of love of money, Machiavellian, and equity sensitivity, which were used in this study. Because these variables are closely related to Tax Moral Theory which is the Grand Theory in this study. Several studies related to love of money, Machiavellian, and equity sensitivity on the perception of tax evasion have indeed been conducted by previous researchers. However, the results of these studies still show contradictory results (inconsistent) between one researcher and another. The inconsistencies in the results of previous studies are probably due to the existence of other variables that influence the taxation system on the perception of tax evasion. In this study, the researcher suspected that religiosity could moderate the effect of love of money, Machiavellian, and equity sensitivity on the perception of tax evasion. This is also based on the theory of planned behavior which states that there are behavioral beliefs that can trigger someone to take unethical actions. This assumes that individuals who have intrinsic religiosity can inhibit and limit individual intentions to evade taxes. Meanwhile, individuals who have extrinsic religiosity can increase the individual's intention to evade taxes.

\section{Literature review and hypotheses}

Frey (1971) introduced a tax moral or also called an individual's intrinsic motivation to act, which is based on values that are influenced by cultural norms. According to this opinion, tax morale can be understood as an explanation of the moral principles or values that a person believes in paying taxes. Fraud Triangle Theory was introduced by Cressey (1953). This theory states that someone will commit fraud if it is based on three reasons, namely pressure, rationalization and opportunity. Muthohiroh (2018) states that these three components influence each other and form a fraud triangle. Ajzen (1991) developed Theory of Reasoned Action (TRA) into another theory, namely Theory of Planned Behavior (TPB) and shows the relationship of behaviors generated by individuals in response to something. Theory of Planned Behavior (TPB) states that in addition to attitudes towards behavior and subjective norms, individuals also consider perceived behavior control, namely the ability to perform these actions. Ardi, et al., (2016) defines perception as an assumption or information from an individual obtained from past experiences felt by that 
individual, as well as the individual's desire to make decisions from information provided by others. Perception arises due to factors that enter into the individual's psychology and will penetrate the individual's mind. This is what causes perception to be able to influence individual actions (Sari, 2020). The literature reveals that tax evasion also shows some difficulties in increasing income in Nigeria (Mansor \& Gurama, 2016). Tax evasion causes economic instability (Mehrara \& Farahani, 2016). Tang (1992) introduced the concept of the love of money as a psychological literature. Individuals with high love of money think money is something good, money ownership is a form of achievement, money is a symbol of freedom, and money is a form of selfconfidence (Astungkara \& Widayanti, 2020). Machiavellian is a belief or perception that is believed about interpersonal relationships. This perception will form a personality that underlies attitudes in dealing with other people. This perception will form a personality which is the basis for determining attitudes in dealing with other people (Setyaniduta \& Hermawan, 2016). Machiavellian personalities have a tendency to manipulate other people, very low respect for others. Simić, et al. (2015) states that Machiavellianism is a dimension of a person's personality that reflects the level of irregularities, including one's efforts to achieve personal interests. According to Asih and Dwijayanti (2019) equity sensitivity is the level of tolerance of an individual for justice received by that individual. Husemen (1987) explained that people have their own perceptions of equity (fair) and inequity (unfair). Religiosity is the internalization of religious values in a person. Internalization related to belief in religious teachings both in heart and in speech (Taswiyah \& Najmudin, 2017). Fajriana (2019) states intrinsic religiosity refers to motivation based on inherent and religious tradition itself. . Extrinsic religiosity is one's approach to religion and reflects one's motivation for social approval (Fajriana, 2019). Based on the results of previous studies that have been presented, the hypothesis in this study is

H1: Love of money has a positive effect on the perception of tax evasion.

$\mathrm{H}$ 2: Machiavellian has a positive effect on the perception of tax evasion.

$\mathrm{H} 3$ : Equity sensitivity has a negative effect on the perception of tax evasion.

$\mathrm{H} 4 \mathrm{a}$ : Intrinsic religiosity weakens the influence of love of money on perceptions of tax evasion.

$\mathrm{H} 4 \mathrm{~b}$ : Extrinsic religiosity strengthens the influence of love of money on the perception of tax evasion.

$\mathrm{H} 5 \mathrm{a}:$ Intrinsic religiosity weakens the machiavellian influence on perceptions of tax evasion.

$\mathrm{H} 5 \mathrm{~b}$ : Religiusitas ekstrinsik memperkuat pengaruh machiavellian pada persepsi penggelapan pajak.

H6a : Intrinsic religiosity strengthens the effect of equity sensitivity on the perception of tax evasion.

$\mathrm{H} 6 \mathrm{~b}$ : Extrinsic religiosity weakens the effect of equity sensitivity on the perception of tax evasion.

\section{Research method}

The research data was collected through a survey method with a questionnaire technique. The population in this study are individual taxpayers who are registered in all primary tax service offices in Bali. The research sample was taken using proportional stratified random sampling technique. The determination of the number of samples taken also used the Yamane formula so that the number of samples in this study was 400 respondents. The number of questionnaires distributed is 400 with a rate of return of $88 \%$ and a rate of return used is $81.50 \%$. The research instrument has also passed the validity and reliability test. Hypothesis testing of multiple linear regression analysis techniques and moderated regression analysis (Moderated Regression Analysis), which is preceded by performing a classical assumption test, namely the normality test and heteroscedasticity test.

\section{Results and discussion}

Table 3

The results of multiple regression analysis

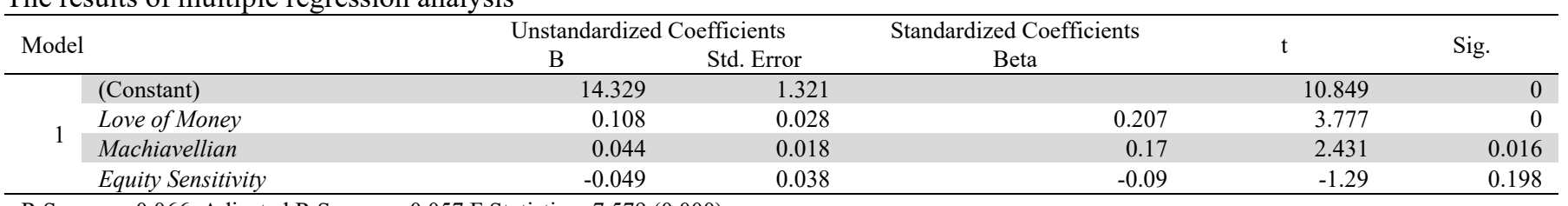

R Square $=0.066$ Adjusted R Square $=0.057$ F Statistic $=7.579(0.000)$

Table 4

Results of Moderation Analysis of Intrinsic Religiosity

\begin{tabular}{|c|c|c|c|c|c|c|}
\hline & \multirow[t]{2}{*}{ Model } & \multicolumn{2}{|c|}{ Unstandardized Coefficients } & \multirow{2}{*}{$\frac{\text { Standardized Coefficients }}{\text { Beta }}$} & \multirow[t]{2}{*}{$\mathrm{T}$} & \multirow[t]{2}{*}{ Sig. } \\
\hline & & $\mathrm{B}$ & Std. Error & & & \\
\hline \multirow[t]{8}{*}{1} & (Constant) & -4.505 & 1.243 & & -3.625 & .000 \\
\hline & Love of Money & .006 & .013 & .011 & .439 & .661 \\
\hline & Machiavellian & .008 & .009 & .033 & .977 & .329 \\
\hline & Equity Sensitivity & -.016 & .017 & -.031 & -.945 & .345 \\
\hline & Religiosity & -.057 & .022 & -.074 & -2.543 & .011 \\
\hline & X1.M1 & -.027 & .001 & -.874 & -19.181 & .000 \\
\hline & X2.M1 & -.003 & .001 & -.146 & -2.204 & .028 \\
\hline & X3.M1 & .010 & .004 & .163 & 2.185 & .030 \\
\hline
\end{tabular}

R Square $=0.808$ Adjusted R Square $=0.804$ F Statistic $=191.248(0.000)$ 
Table 5

Results of Extrinsic Religiosity Moderation Regression Analysis

\begin{tabular}{|c|c|c|c|c|c|c|}
\hline \multirow{2}{*}{ Model } & & \multicolumn{2}{|c|}{ Unstandardized Coefficients } & \multirow{2}{*}{$\begin{array}{c}\text { Standardized Coefficients } \\
\text { Beta }\end{array}$} & \multirow{2}{*}{$\mathrm{T}$} & \multirow{2}{*}{ Sig. } \\
\hline & & $\mathrm{B}$ & Std. Error & & & \\
\hline \multirow{8}{*}{1} & (Constant) & 2.503 & 0.701 & & 3.569 & 0 \\
\hline & Love of Money & 0.004 & 0.013 & 0.007 & 0.284 & 0.777 \\
\hline & Machiavellian & 0.007 & 0.009 & 0.028 & 0.837 & 0.403 \\
\hline & Equity Sensitivity & -0.015 & 0.017 & -0.028 & -0.874 & 0.383 \\
\hline & Religiosity & 0.073 & 0.032 & 0.091 & 2.319 & 0.021 \\
\hline & X1.M2 & 0.026 & 0.002 & 0.841 & 15.904 & 0 \\
\hline & X2.M2 & 0.003 & 0.001 & 0.142 & 2.124 & 0.034 \\
\hline & $\mathrm{X} 3 . \mathrm{M} 2$ & -0.009 & 0.004 & -0.156 & -2.075 & 0.039 \\
\hline
\end{tabular}

R Square $=0.807$ Adjusted R Square $=0.803$ F Statistic $=190.454(0.000)$

\subsection{The Effect of Love of Money on Perceptions of Tax Evasion}

The results of the regression analysis show that love of money has a positive and significant effect on the perception of tax evasion (H1 accepted). This means that the higher the love of money attitude will increase the perception of tax evasion, namely the high sense of love of taxpayers for money will further increase the perception of tax evasion. The results of this study are in accordance with the Theory Planned Behavior (TPB), this is because the TPB theory supports the behavior of taxpayers to pay taxes. TPB shows that human actions are directed by three kinds of beliefs, namely behavioral beliefs, normative beliefs and control beliefs. Love of money in this study relates to behavioral beliefs. Tang (1992) introduced the concept of the love of money which measures a person's subjective feelings about money. High money ethics is also called the love of money, namely someone who places great importance on money and considers money to be everything in life. Someone who has high money ethics will be less ethical than people with low money ethics. According to Oktaviani (2019) someone who has a perception of a high love for money tends to cause tax evasion. This study supports the research results of Mitayani (2019), Basri (2015), Asih \& Dwiyanti (2019) and Farhan, et al., (2019) which in their research found that love of money has a significant effect on taxpayers' perceptions of tax evasion ethics. Individuals who have a high level of love for money will be increasingly unwilling to spend money on things that do not provide direct returns, such as tax payments. For individuals who have a high level of love for money, paying taxes is an action that is considered not directly beneficial and feels a loss when they have to spend money on tax payments imposed on income earned, so it tends to cause a higher perception of tax evasion.

\subsection{Machiavellian Effect on Perceptions of Tax evasion}

The results of the regression analysis show that the Machiavellian nature has a positive and significant effect on the perception of tax evasion (H2 is accepted). This means that the higher the Machiavellian attitude will have an impact on increasing the perception of tax evasion, namely the high Machiavellian nature of the taxpayer will further increase the perception of tax evasion. The results of this study are in accordance with the Tax Morale Theory. This theory states the perception of honesty. Honesty in this case is closely related to Machiavellian behavior, that is, someone who has high Machiavellian tends to behave unethically, then is more likely to commit tax evasion. According to Devi and Ramanta (2017), someone who has a high Machiavellian nature, tends not to care about the importance of the value of honesty and integrity, besides that, he also tends to disobey the rules. Machiavellian personalities have a tendency to manipulate other people, very low respect for others. Machiavellian is usually associated with individuals who are manipulative, use persuasive behavior to achieve personal goals, and are usually aggressive (Novitasari, 2016). The Fraud Triangle Theory in which there is one factor, namely rationalization, is also closely related to Machiavellian characteristics. Rationalization as a whispered justification against the conscience of the perpetrator of fraud. Machiavellian individuals will tend to be rational to commit tax evasion. This study supports the results of research by Ramadhani (2015) which suggests that the machiavellian nature has an effect on ethical decision making, in this case, tax avoidance. The effect in question is the high Machiavellian nature of a person, indicating that the decisions he will take are increasingly unethical, so that he tends to commit tax evasion. In this study, taking the point of view of individual taxpayers, so that the perception of tax evasion is an ethical perception.

\subsection{Effect of Equity Sensitivity on Perceptions of Tax Evasion}

The result of regression analysis shows that equity sensitivity does not have a significant effect on the perception of tax evasion (H3 is rejected). Where equity sensitivity is an individual's perception of fairness by comparing the input and outcome. Every individual has a different preference for justice which causes different reactions. In this case, equity sensitivity is declared unable to affect the ethical behavior of individual taxpayers in the Bali region in terms of fulfilling their tax obligations where taxpayers are not triggered to commit unethical actions, namely tax evasion for justice received because something is fair or not is relative, where the measure of a person's justice is determined by himself. An action or policy that is considered fair according to the 
individual, it is not certain that other individuals also feel that justice, also the opposite applies. This study supports the results of Asih and Dwijayanti's (2019) research which states that equity sensitivity does not affect ethical perceptions of tax evasion. Dwitya, et al. (2020) also found that equity sensitivity had no effect on perceptions of tax evasion. However, this study is not in line with the results of Titaresmi's (2018) research which states that equity sensitivity has a positive effect on ethical behavior of accounting students.

\subsection{Religiosity moderates the effect of love of money on perceptions of tax evasion}

The results of the regression analysis show that intrinsic religiosity weakens the effect of love of money on the perception of tax evasion (H4a accepted). This means that the higher a person's intrinsic religiosity, the higher one's belief in religion and behavior becomes more ethical, so that the influence of love of money on the perception of tax evasion can be reduced by the presence of intrinsic religiosity. The results of the analysis also show that extrinsic religiosity strengthens the effect of love of money on the perception of tax evasion (H4b accepted). This means that the higher the WPOP extrinsic religiosity will increase the effect of love of money on the perception of tax evasion. People who have high extrinsic religiosity, the lower their ethics, and the more likely to commit tax evasion. The results of this study are in accordance with the Theory of Planned Behavior which explains that a person's needs are not only influenced by subjective intentions and norms, but also influenced by control beliefs. In the TPB theoretical model, it is stated that there are background factors that influence a person's intentions, subjective norms and control beliefs. These factors can be in the form of personal, social and information factors. Social factors include age, gender, ethnicity, education, income and religion. This study supports the results of Novitasari's (2016) research finding that love of money affects the ethical perceptions of accounting students. Supported by research by Nauvalia, et al. (2018) and Dewanta \& Machmuddah (2019) which show that love of money has a simultaneous effect on perceptions of tax evasion.

\subsection{Religiosity Moderates the Machiavellian Effect on Perceptions of Tax Evasion}

The result of moderation regression analysis shows that intrinsic religiosity weakens the Machiavellian influence on the perception of tax evasion (H5a accepted). This means that the higher the intrinsic religiosity a person has, the higher one's belief in religion and behavior becomes more ethical, so that the machiavellian influence on the perception of tax evasion can be reduced by the presence of intrinsic religiosity. The results of this study are in accordance with the Tax Morale Theory associated with religiosity. Evidenced by Pertiwi's research (2017), in his research it concluded that religiosity still plays an important role in decision-making in the Muslim community. Thus, if tax policy makers can touch the religious side of the Muslim community, which in fact is the majority, it is hoped that tax revenue can increase. These results support the research of Hafizhah (2016) which states that the intrinsic religiosity that exists in a person can control every action he does. When someone whose intrinsic religiosity is good, then the Machiavellian behavior will be far from that person, and behave ethically. The analysis also shows that extrinsic religiosity strengthens the Machiavellian influence on the perception of tax evasion (H5b accepted). This means that higher WPOP extrinsic religiosity will increase the Machiavellian influence on the perception of tax evasion. People who have high extrinsic religiosity, the lower their ethics, and the more likely to commit tax evasion. Extrinsic religiosity is one's approach to religion and reflects one's motivation for social approval (Fajriana, 2019). Individuals who have extrinsic religiosity use religion for various purposes, to gain security, overcome confusion, gain protection, status and self-improvement and choosing from his religious teachings to do so in order to benefit oneself according to the necessary needs. Thus, extrinsic religiosity does not change a person's personality. People who behave highly Machiavellian will remain Machiavellian, because the teachings and principles of religion do not enter into individuals, but religion is only a social status and social support, so that individuals will continue to behave unethically. This study supports the research results of Wade et al., (2019) and Prabowo and Widanaputra (2018) which state that Machiavellian affects ethical behavior.

\subsection{Religiosity Moderates the Effect of Equity Sensitivity on Perceptions of Tax Evasion}

The result of moderation regression analysis shows that intrinsic religiosity strengthens the effect of equity sensitivity on the perception of tax evasion (H6a accepted). This means that the higher the intrinsic religiosity a person has, the higher one's belief in religion will be, and behaves more ethically, so that the effect of equity sensitivity on the perception of tax evasion increases with the presence of intrinsic religiosity. The results of this study are in accordance with the Tax Morale Theory, where this theory holds that between the community and the government there is an implicit contract in which the community realizes that the community has rights and obligations. If the government is able to get sympathy from the public, by providing support in the field of religion, then the public will respect the government and the perception of taxpayers to commit tax evasion will decrease. These results support the research results of Widiastuti and Eni (2015) which found that there was an effect of equity sensitivity on auditors' ethical behavior. The results of the analysis also show that extrinsic religiosity weakens the effect of equity sensitivity on the perception of tax evasion (H6b accepted). This means that higher WPOP extrinsic religiosity will reduce the effect of equity sensitivity on the perception of tax evasion. The results of this study are in accordance with the Tax Morale Theory which states the individual's intrinsic motivation to act, which is based on values that are influenced by cultural norms. In this case, religion is 
closely related to culture. Individuals who have extrinsic religiosity use religion for various purposes, to gain security, overcome confusion, gain protection, status and self-improvement. Choosing from his religious teachings to do so in order to benefit oneself according to the necessary needs. Equity sensitivity is an individual's perception of fairness by comparing the amount of expenditure incurred by an individual with the income that individual earns from other people. In this case, equity sensitivity is in line with several factors contained in the tax morale theory, namely the second, third, and fourth factors. If there is a good relationship between tax officials and taxpayers and tax officials are able to provide output that is in accordance with the input of the taxpayer, then taxpayers will no longer hesitate to pay their taxes. The results of this study support the results of research conducted by Widiastuti and Nugroho (2015) who found evidence that there is an effect of equity sensitivity on auditors' ethical behavior.

\section{Conclusion}

The results of this study have indicated that love of money and machiavellian nature have positive effects on the perception of tax evasion, but equity sensitivity has no effect on the perception of tax evasion. The subsequent test results have provided empirical evidence that intrinsic religiosity and extrinsic religiosity can moderate the effects of love of money, machiavellian nature, and equity sensitivity on perceptions of tax evasion. This study contains several limitations in which the perception of individual taxpayers who are registered in the Bali region's premier tax service office only so that it cannot be generalized to all Pratama tax service offices in Indonesia. Future research can use this research as a reference regarding the perceptions of taxpayers who are registered in other Pratama tax service offices. The R-Square value of 0.804 indicates that $80.4 \%$ of the perception of tax evasion was influenced by the love of money, machiavellian and equity of sensitivity variables moderated by intrinsic religiosity, while $19.6 \%$ was influenced by other variables not presented in this research model. The R2 value of 0.803 shows that $80.3 \%$ of the perception of tax evasion is influenced by the love of money, machiavellian and equity of sensitivity variables moderated by extrinsic religiosity, while $19.7 \%$ is influenced by other variables not presented in this research model. This is an opportunity for further researchers to develop research related to other factors that influence the perception of tax evasion such as tax sanctions, tax apparatus services, tax justice, technology and tax information.

\section{References}

Ajzen, I. (1991). The theory of planned behavior. Organizational Behavior And Human Decision Processes, $50(2), 179-211$. Ardi, D. M. (2016). Pengaruh Persepsi Wajib Pajak Orang Pribadi Terhadap Tindakan Penggelapan Pajak Di Kota Surakarta. Anonim. (2015). Kanwil DJP Jabar | Bekuk Tersangka Penggelapan Pajak. Https://Www.Pajak.Go.Id/Id/Kanwil-Djp-Jabar-IBekuk-Tersangka- Penggelapan-Pajak. (12 Februari 2020).

Anonim. (2015). Putusan Pengadilan Negeri Palembang Atas Penggelapan Pajak Oleh Bendahara.Https:/Www.Pajak.Go.Id/Id/Putusan-Pengadilan-Negeri- Palembang-Atas-Kasus-Penggelapan-Pajak-OlehBendahara. (12 Februari 2020).

Anonim. (2018). Kejari Tangkap Terdakwa Korupsi Pajak Reklame. Https://Www.Ortax.Org/Ortax/? Mod=Berita\&Page=Show $\& \mathrm{Id}=16350 \& \mathrm{Q}=$ Penggelapan $\& H \mathrm{~lm}=1$. (12 Februari 2020).

Anonim. (2018). Kepala KPP Pratama Ambon Cs Ditangkap KPK Karena Suap. Https:/Www.Ortax.Org/Ortax/?Mod=Berita\&Page=Show\&Id=16319\&Q=Ambo N\&Hlm=1. (12 Februari 2020$)$.

Anonim. (2019). Tak Bayar Pajak Rp4,4 Miliar, Perusahaan Ini Dipasang Plang. Https://Www.Ortax.Org/Ortax/?Mod=Berita\&Page=Show\&Id=16762\&Q=Darwi N\&Hlm=1. (12 Februari 2020)

Anonim. (2019). Tersangka Darwin Palani Pemeriksaan Https://Www.Ortax.Org/Ortax/?Mod=Berita\&Page=Show\&Id=16762\&Q=Darwi N\&Hlm=1. (12 Februari 2020)

Anonim. (2020). Penggelapan Pajak Hotel Hanging Garden Disidangkan, Korban Berharappelaku Lain Terungkap. Https://Www.Bali.Tribunnews. Com/Amp/2020/01/08/Penggelapan-Pajak-Hotel-Hanging-Garden-Disidangkan-KorbanBerharap-Pelaku-Lainterungkap?Page=2

Asih, N. P. S. M., \& Dwiyanti, K. T. (2019). Pengaruh love of money, machiavellian, and equity sensitivity Terhadap Persepsi Etika Penggelapan Pajak (Tax Evasion). E-Jurnal Akuntansi, 26(2), 1412-1435.

Astungkara, A., \& Widayanti, R. (2020). Peran Pendidikan Kewirausahaan Dan Love Of Money Terhadap Intensi Berwirausaha Pada Mahasiswa Akuntansi. Jurnal Akuntansi Dan Pajak, 20(2).

Basri, Y. M. (2015). Pengaruh Gender, Religiusitas Dan Sikap Love Of Money Pada Persepsi Etika Penggelapan Pajak Mahasiswa Akuntansi. Jurnal Ilmiah Akuntansi Dan Bisnis, 10(1), 45-54.

Budiarto, D. S., \& Nurmalisa, F. (2018). Hubungan Antara Religiusitas Dan Machiavellian Dengan Tax Evasion: Riset Berdasarkan Perspektif Gender. Telaah Bisnis, 18(1).

Dewanta, M. A., \& Machmuddah, Z. (2019). Gender, Religiosity, Love Of Money, And Ethical Perception Of Tax Evasion. Jurnal Dinamika Akuntansi Dan Bisnis, 6(1), 71-84. 
Dewi, I. G. P. E. R. (2019). Filosofi Tri Kaya Parisudha Memoderasi Pengaruh Equity Sensitivity Dan Ethical Sensitivity Pada Perilaku Etis Auditor Badan Pemeriksa Keuangan Perwakilan Provinsi Bali. Jurnal Penjaminan Mutu, 5(1), 43-56.

Dhanayanti, K. M., \& Suardana, K. A. (2017). Pengaruh Persepsi Wajib Pajak Mengenai Penggelapan Pajak Dan Keadilan Sistem Perpajakan Pada Kepatuhan Pajak. E-Jurnal Akuntansi Universitas Udayana, 20, 1504-1533.

Dwitya, Esther., Masripah., Widiastuti, \& Ni Putu Eka. (2020). Taxpayer Perception Related To Love Of Money, Machiavellian, And Equity Sensitivity On Tax Evasion Ethics. Jurnal Akuntansi Dan Perpajakan, 2(1)

Fajriana, I. (2019). Pengaruh Keterkaitan Religiusitas, Sosial Ekonomi Dan Sikap Love Of Money Dalam Etika Penggelapan Pajak Wajib Pajak UMKM Di KPP Pratama Palembang Ilir Barat. Jurnal Ilmiah STIE MDP, 8(2)

Farhan, M., Helmy, H., \& Afriyenti, M. (2019). Pengaruh Machiavellian Dan Love Of Money Terhadap Persepsi Etika Penggelapan Pajak Dengan Religiusitas Sebagai Variabel Moderasi. JURNAL EKSPLORASI AKUNTANSI, 1(1), 470-486.

Frey. (1997). The Role Of Deterrence And Tax Morale In Taxation In The European Union. Jelle Ziilstra Lecture, Netherlands Institution For Advance Study In The Hummanities And Social Sciences (NIAS)

Mansor, M., \& Gurama, Z. U. (2016). The Determinants Of Tax Evasion In Gomba State Nigeria. International Journal Of Economics And Financial Issues, 6(S7), 165-170.

Mardiasmo. (2016). Perpajakan Edisi Terbaru. Andi, Yogyakarta.

Marta, D. (2016). Pengaruh Persepsi Wajib Pajak Orang Pribadi Terhadap Tindakan Penggelapan Pajak Di Kota Surakarta. Economica, 4(2)

Mcgee, R., \& Shopovski, J. (2018). The ethics of tax evasion: A survey of law and economics students in the republic of Macedonia. International Journal Of Economic Sciences, 7(2).

Nugraheni, A., D \& Purwanto, A. (2015). Faktor - Faktor Yang Mempengaruhi Kepatuhan Wajib Pajak Orang Pribadi (Studi Empiris Pada Wajib Pajak Di Kota Magelang). Diponogoro Journal Of Accounting, 4(3).

Mehrara, M., \& Farahani, Y. G. (2016). The study of the effects of tax evasion and tax revenues on economic stabilities in OECD countries. World Scientific News, 33

Mitayani. (2019). Pengaruh Pemahaman Perpajakan, Love Of Money, Religiusitas, Norma Subjektif, Dan Kemungkinan Terdeteksi Kecurangan Terhadap Persepsi Wajib Pajak Mengenai Etika Penggelapan Pajak. Skripsi Fakultas Ekonomi Dan Bisnis Universitas Muhammadiyah Surakarta.

Mujiyati, M., Rohmawati, F. R., \& Ririn, W. H. (2018). Determinan Persepsi Mengenai Etika Atas Penggelapan Pajak (Tax Evasion). Riset Akuntansi Dan Keuangan Indonesia, 3(1)

Muthohiroh, D., I., L. (2018). Deteksi Potensi Penggelapan Pajak Berbasis Fraud Triangle. Jurnal Ilmiah Mahasiswa FEB Universitas Brawijaya, 6(2)

Nauvalia, F. A., Hermawan, Y., \& Sulistyani, T. (2018). Pengaruh Religiusitas, Pemahaman Perpajakan, Status Sosial Ekonomi Dan Love Of Money Terhadap Persepsi Penggelapan Pajak. PERMANA, 9(2).

Novitasari, E. D., \& Sukirno, S. (2016). Pengaruh Love Of Money Dan Perilaku Machiavellian Terhadap Persepsi Etis Mahasiswa Akuntansi (Studi Kasus Pada Mahasiswa S1 Program Studi Akuntansi Angkatan 2010 Dan 2011 Fakultas Ekonomi Universitas Negeri Yogyakarta). Jurnal Profita: Kajian Ilmu Akuntansi, 4(3).

Oktaviani, R. M., Srimindarti, C., \& Hardiningsih, P. (2018). Peran Religionsity Sebagai Pemoderasi Hubungan Money Ethics Terhadap Upaya Tax Evasion. Jurnal Akuntansi, 22(1), 105-118.

Pertiwi, I. F. P. (2017). Moral Pajak: Sebuah Opsi Peningkatan Kepatuhan Pajak Masyarakat Muslim. Jurnal Al-Qardh, 2(1), 1225.

Prabowo, P. P., \& Widanaputra, A. P. (2018). Pengaruh Love Of Money, Machiavellian, Dan Idealisme Pada Persepsi Etis Mahasiswa Akuntansi. E-Jurnal Akuntansi, 23(1), 513-537.

Sari, D. P. (2020). Persepsi Wajib Pajak Terhadap Citra Perpajakan Indonesia Setelah Fenomena Kasus Korupsi Pajak. Akutansi Bisnis \& Manajemen (Abm), 27(1), 15-28.

Sari, M. M. R., Wirajaya, I. G. A., \& Supadmi, N. L. Gender Memoderasi Pengaruh Love Of Money Terhadap Tax Evasion Tendency. Jurnal Ekonomi Kuantitatif Terapan, 197-211.

Setyaniduta, G. I. P., \& Hermawan, S.(2016, October). Sifat Machiavellian, Perkembangan Moral, Locus Of Control, Dan Pengaruhnya Terhadap Dysfunctional Audit Behavior. In National Seminar On Accounting And Finance 2016, Universitas Negeri Malang.

Simić, I., Matović, I. M., \& Stojković, N. (2016). Analysis Of Machiavellian Behavior Of Students In The Republic Of Serbia. Facta Universitatis, Series: Economics And Organization, 199-208.

Sofha, D., \& Machmuddah, Z. (2019). Persepsi Etika Penggelapan Pajak: Pengaruh Langsung Dan Tidak Langsung. Akuntabilitas, 12(1), 65-82.

Tang, T. L. P. (1992). The meaning of money revisited. Journal Of Organizational Behavior, 13(2), 197-202.

Taswiyah, T., \& Najmudin, N. (2017). Pengaruh Religiusitas Terhadap Perilaku Ekonomi Masyarakat Pasar Tradisional (Studi Empiris Pada Masyarakat Pasar Tradisional Di Kota Serang Provinsi Banten). Al Qalam, 34(2), 313-336.

Titaresmi, K. Y. (2018). Pengaruh Equity Sensitivity, Ethical Sensitivity, Dan Gender Terhadap Perilaku Etis Mahasiswa Akuntansi Pada Stiesia Surabaya. Jurnal Ilmu Dan Riset Akuntansi (Jira), 7(9). 
Wade, R., Kepramareni, P., \& Pramesti, I. G. A. A. (2019). Pengaruh Love Of Money Dan Machiavellian Terhadap Persepsi Etis Mhasiswa Akuntansi Fakltas Ekonomi Universitas Mahasaraswati Denpasar. Kumpulan Hasil Riset Mahasiswa Akuntansi (Kharisma), 1(1), 276-289.

Widiastuti, E., \& Nugroho, M. A. (2015). Pengaruh Orientasi Etis, Equity Sensitivity, Dan Budaya Jawa Terhadap Perilaku Etis Auditor Pada Kantor Akuntan Publik Di Yogyakarta. Nominal: Barometer Riset Akuntansi Dan Manajemen, 4(1), $32-48$.

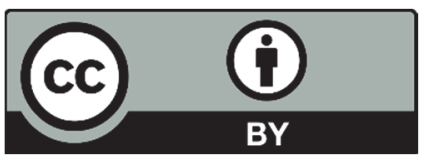

(C) 2021 by the authors; licensee Growing Science, Canada. This is an open access article distributed under the terms and conditions of the Creative Commons Attribution (CC-BY) license (http://creativecommons.org/licenses/by/4.0/). 